\title{
Antitrust and the New State Action Doctrine: A Return to Deferential Economic Federalism
}

\author{
Thomas M. Jorde $\uparrow$
}

Some amount of conflict is inevitable between federal antitrust laws and state economic regulation. Written in broad strokes, federal antitrust prohibits combinations in restraint of trade or monopolization of markets, and thus confirms competition in free markets as the fundainental principle governing the national economy. ${ }^{1}$ In the eloquent words of the Supreine Court,

[federal antitrust law] rests on the premise that the unrestrained interaction of competitive forces will yield the best allocation of our economic resources, the lowest prices, the highest quality and the greatest material progress, while at the saine timie providing an environment conducive to the preservation of our democratic political and social institutions. ${ }^{2}$

State economic regulation, on the other hand, usually supplants coinpetition and free markets. For exainple, states commonly regulate utilities, hicense professions, zone property, limit taxicab permits, or place other price or entry controls upon selected businesses. Although state regulation is often desigued to correct perceived market failures, ${ }^{3}$ much of it is economically mefficient and thus in conflict with federal antitrust policy. ${ }^{4}$

If strict preemption standards were applied to this conflict betweeen federal antitrust laws and state economic regulation, the supremacy clause of the Constitution would require the wholesale invalidation of

$\dagger$ Professor of Law, Boalt Hall School of Law, University of California. B.A. 1969, J.D. 1972, Yale University. I wish to thank Michael Kane, Boalt Hall Class of 1986, and David Levant, Boalt Hall Class of 1987, for excellent research assistance, and my colleagues, Robert Post, Dan Rubinfeld, and Harry Scheiber, for their thoughtful comments. Portions of this essay were delivered at the 1986 Berkeley Seminar on Federalism, University of California, Berkeley, Noveniber 13-14, 1986.

1. See, e.g., City of Lafayette v. Louisana Power \& Light Co., 435 U.S. 389, 398 (1978)

2. Northern Pac. Ry. v. United States, 356 U.S. 1, 4 (1958).

3. Market failures or imperfections typically include natural monopoly, externalities, and excessive competition. See S. BREYER, Regulation AND ITS Reform 15-34 (1982); 2 A. KAHN, THE ECoNomics of Regulation 116-23, 172-78, 221-24, 236-44 (1971); L. SCHWARTZ, J. FLYNN \& H. FIRST, FREE ENTERPRISE AND ECONOMIC ORGANIZATION: GOVERNMENT REGULATION 6471 (6th ed. 1985).

4. Of course, the state may also regulate for health or safety reasons. The focus of this essay is upon nore direct economic regulation. 
state regulatory regimes. ${ }^{5}$ This result has largely been avoided by the "state action" doctrine, a judicially crafted accommodation of state sovereignty reached in Parker v. Brown, ${ }^{6}$ that exempts the actions of a sovereigu state from the coverage of the antitrust laws. ${ }^{7}$

Defining the scope of the state action doctrine-and hence the extent of deference to be accorded state economic choices-has been a difficult task for the Supreme Court. During the past ten years the Court has struggled to develop and apply tests that would distinguish state activity, which the state action doctrine exempts, from private activity, which remains subject to the federal antitrust laws. ${ }^{8}$ In a trilogy of cases-Hoover v. Ronwin, ${ }^{9}$ Town of Hallie v. City of Eau Claire, ${ }^{10}$ and Southern Motor Carriers Rate Conference v. United States (SMC) ${ }^{11}$-the Court substantially clarified this important area of antitrust and econoinic federalism. ${ }^{12}$

The aim of this essay is to sketch the evolution of the state action doctrine in order to demonstrate that it now provides states a relatively free hand to regulate their economies without fear of federal antitrust prosecution and that the current doctrine accords well with the principles underpinning economic federalism. ${ }^{13}$ I will first show that the roots of the state action doctrine are found in the values of economic federalism. As the doctrine developed, the Court tended to lose sight of these values, first flirting with substantive economic review and then turning to

5. U.S. Const. art. VI, cl. 2; see, e.g., Handler, Changing Trends in Antitrust Doctrines: An Unprecedented Supreme Court Term-1977, 77 ColuM. L. REv. 979, 1015-16 (1977); Handler, Antitrust-1978, 78 Colum. L. Rev. 1363, 1381 (1978); Page, Antitrust, Federalism, and the Regulatory Process: A Reconstruction and Critique of the State Action Exemption After Midcal Aluminum, 61 B.U.L. REv. 1099, 1107 (1981); Note, The Preemption Doctrine: Shifting Perspectives on Federalism and The Burger Court, 75 CoLuM. L. REv. 623 (1975).

6. 317 U.S. 341 (1943).

7. Occasionally, the Court has resolved potential conflict between the federal antitrust laws and state regulation by interpreting the state statute or regulatory behavior in a manner that avoids conflict with the antitrust laws. See, e.g., Fisher v. City of Berkeley, 106 S. Ct. 1045 (1986); Rice v. Norman Williams Co., 458 U.S. 654, 661 (1982); Exxon Corp. v. Governor of Maryland, 437 U.S. 117,131 (1978). If conflict cannot be avoided by such interpretation, the Court then turns to state action exemption analysis.

8. See Community Communications Co. v. City of Boulder, 455 U.S. 40 (1982); California Retail Liquor Dealers Ass'n v. Midcal Aluminum, Inc., 445 U.S. 97 (1980); City of Lafayette v. Louisiana Power \& Light Co., 435 U.S. 389 (1978); Bates v. State Bar, 433 U.S. 350 (1977); Cantor v. Detroit Edison Co., 428 U.S. 579 (1976); Goldfarb v. Virginia State Bar, 421 U.S. 773 (1975).

9. 466 U.S. 558 (1984).

10. 471 U.S. 34 (1985).

11. 471 U.S. 48 (1985).

12. The Court's most recent state action pronouncements in 324 Liquor Corp. v. Duffy, $107 \mathrm{~S}$. Ct. 720 (1987) are in step with these clarifications. See infra text accompanying notes 126-28.

13. Of course, Congress might respond by enacting substantive legislation that would preempt a particular area of state regulation, or the negative commerce clause may operate to strike down discriminatory state regulation. See infra text accompanying notes 33-38. But absent such responses, the antitrust laws themselves will not be an effective bar to state and local regulation. 
a rigorous process-oriented test that was very difficult for states to meet. The Court's recent trilogy of cases returns to deferential economic federahsm by creating a leirient process-oriented test for identifying exempt state action. In a concluding section, I argue that the Court's new approach strikes an appropriate balance between federal antitrnst pohcies and economic federalism values and, in particular, is strongly supportive of the citizen participation value. I also suggest what congressional and judicial developments might be expected in this area.

\section{The Original State Action Doctrine}

\section{A. Parker v. Brown}

In Parker the Court was called upon to decide whether California's Agricultural Prorate Act, which effectively cartelized the state's raisin producers by restricting the output and raising the price of raisins, violated the Sherman Act. The Court found that while Congress had the power under the commerce clause to prohibit anticompetitive state programs, it did not intend to prohibit the states from regulating their domestic economies: "We find nothing in the language of the Shernian Act or in its history which suggests that its purpose was to restrain a state or its officers or agents from activities directed by its legislature."14 In short, the Sherman Act is "a prohibition of individual and not state action."15

The Court's narrow interpretation of legislative intent is not surprising. In 1890 when the Sherman Act was passed, Congress would not have thought it had authority under the commerce power to extend the antitrust laws to the activities of a state sovereign. ${ }^{16}$ Nevertheless, the importance of the Court's approach cannot be underestimated. By construing the Sherman Act to apply only to the activities of private parties, the Court avoided the difficult tenth amendment problems it has lately

14. Parker, 317 U.S. at $350-51$.

15. Id. at 352. The Court also noted that "a state does not give immunity to those who violate the Sherman Act by authorizing them to violate it, or by declaring that their action is lawful." Id. at 351. The Sherman Act would preempt such an attempt by the state because Congress clearly expressed its intention that the activities of private parties are covered by the Act. The state action exemption only comes into play when the state itself or its official agents or delegees act. Thus, it seems reasonably clear that the Sherman Act would preempt a state law that attempted to give blanket immunity from the antitrust laws to a particular industry or sector of the state's economy.

16. See, e.g., Cantor, 428 U.S. at 632-33 (Stewart, J., dissenting); Hovenkamp \& Mackerron, Municipal Regulation and Federal Antitrust Policy, 32 UCLA L. REV. 719, 725-28 (1985); Slater, Antitrust and Government Action: A Formula for Narrowing Parker v. Brown, 69 Nw. U.L. REv. 71, 84-85 (1974). Of course, the reach of the Sherman Act has expanded as the commerce power has grown. See Hospital Bldg. Co. v. Rex Hosp. Trustees, 425 U.S. 738, 743 n.2 (1976); L. SullivaN, HANDBOOK OF THE LAW OF ANTITRUST 708-09 (1977). 
struggled with in National League of Cities v. Usery ${ }^{17}$ and Garcia v. San Antonio Metropolitan Transit Authority. ${ }^{18}$

The Parker Court did not rest the state action exemption on legislative intent alone. Significantly, the Court also grounded the doctrine and its own judicial restraint on the structure of federalisin: "In a dual system of government in which, under the Constitution, the states are sovereign, save only as Congress may constitutionally subtract from their authority, an unexpressed purpose to nullify a state's control over its officers and agents is not lightly to be attributed to Congress." 19

Thus, from its inception, the state action doctrine has been rooted in federalisin principles that value deference to the economic self-deternination of states. ${ }^{20}$ The dual sovereignty structure of government permits states wide latitude to select their own inix of competition and regulation, even if some regnlation is economically inefficient or otherwise anticompetitive.

\section{B. The Values of Federalism}

By anchoring the state action doctrine to federahism, the Court affirmed and advanced the values of federahism: citizen participation in

17. 426 U.S. 833 (1976). See Davidson \& Butters, Parker and Usery: Portended Constitutional Limits on the Federal Interdiction of Anticompetitive State Action, 31 VAND. L. REv. 575, 597.604 (1978).

18. 469 U.S. 528 (1985). Garcia overruled Usery's holding that the tenth amendment immunized certain integral or traditional state governmental functions from federal regulation. For the current majority of five justices, the federal political process and constitutional structure of government-not the tenth amendment-safeguard the states against unduly burdensome commerce clause regulations. Id. at 557. Thus, after Garcia, there would appear to be no constitutional impediment to Congress's amending the federal antitrust laws in a manner that eliminates the state action exemption and makes the antitrust laws fully applicable to state activities. On the other hand, if Usery were still good law (or if it were to become the law once again, as forecast by Justices Rehnquist and O'Connor in their Garcia dissents), then there would be a tenth amendment question as to whether certain state economic regulation constitutes an integral or traditional government function that must be free of federal interference. Justice O'Connor appears to take a fairly expansive view of the state and local regulations that should be shielded by the tenth amendment. See id. at 580 (O'Connor, J., dissentimg); Federal Energy Regulatory Comm'n v. Mississippi, 456 U.S. 742, 779 (1982) (O'Connor, J., concurring and dissenting) [hereinafter FERC].

19. 317 U.S. at 351 . The Court has frequently reiterated the federalism foundation of the state action doctrine. See, e.g., Lafayette, 435 U.S. at 400 (Parker advanced "policies of signal importance in our national traditions and governmental structure of federalism."); Midcal, 445 U.S. at 103 ("Parker iminnnity for state regulatory programs is grounded in our federal structure."); Town of Hallie v. City of Eau Claire, 471 U.S. 34, 38 (1985) ("In Parker, relying on principles of federalisin and state sovereignty, the Court refused to construe the Sherman Act as applying to the anticompetitive conduct of a State acting through its legislature."). The Court's most recent statement is in 324 Liquor Corp. v. Duffy, 107 S. Ct. 720, 725 (1987) ("Parker v. Brown rests on principles of federalism and state sovereignty.").

20. The Court's own unsatisfying experience with economic due process during the Lochner era, just prior to Parker, no doubt increased the Court's sensitivity to the importance of independent state economic choices. See Page, supra note 5, at 1104 \& n.29; Verkuil, State Action, Due Process and Antitrust: Reflections on Parker v. Brown, 75 Colum. L. Rev. 328, 329 (1975). 
government, efficiency in government, creative experimentation, and diffusion of power. These values have been the subject of extensive writing; ${ }^{21}$ iny purpose here is to sketch thein briefly and to note how they are served by the decentralized economic decisionmaking nade possible by Parker.

\section{Citizen Participation}

Citizen participation in government is a fundamental value justifying our federalist system of government. ${ }^{22}$ Indeed, there inay be no greater democratic value than the freedom to participate in the political life of a community. ${ }^{23}$ Active participation revitalizes the values of selfgovernment. ${ }^{24}$ It is "a means of strengthening the representativeness of governinental institutions and enhancing the perception of its legitimacy." 25 When government operates on a sinaller scale, individuals can participate nore effectively and more directly. ${ }^{26}$ Proximity increases access, communication, and accountability between citizens and public officials. ${ }^{27}$

21. See, e.g., J. Choper, Judicial Review and the National Political Process 247-49 (1980); J. ELy, DEMOCRACY AND Distrust 73-104 (1980); Nagel, Federalism as a Fundamental Value: National League of Cities in Perspective, 1981 SUP. CT. REv. 81; Rapaczynski, From Sovereignty to Process: The Jurisprudence of Federalism After Garcia, 1985 SuP. CT. REv. 341; Scheiber, Federalism and Legal Process: Historical and Contemporary Analysis of the American System, 14 L. \& Soc'Y REv. 663, 689-92 (1980).

22. For example, Justice O'Connor noted that:

Alexis de Tocqueville understood well that participation in local government is a comerstone of American democracy:

It is incontestably true that the love and the habits of republican government in the United States were engendered in the townships and in the provincial assemblies. [I] $t$ is this same republican spirit, it is these manners and customs of a free people, which are engendered and nurtured in the different States, to be afterwards applied to the country at large. 1 A. de Tocqueville, Democracy in America 181 (H. Reeve trans. 1961).

FERC, 456 U.S. at 789-90 (O'Connor, J., concurring and dissenting) (citation in original); see also J. ELY, supra note 21, at 73-104; Rapaczynski, supra note 21, at 395-96, 399-405.

23. Kaden, Politics, Money, and State Sovereignty: The Judicial Role, 79 CoLum. L. REv. 847, 853-56 (1979) ("One clear value of the federal form resides in its potential to provide inaximum opportunities for participation in government... Political liberty - the freedom to participate in the community's political life-is the core of dennocratic government.").

24. FERC, 456 U.S. at 790 (O'Connor, J., concurring and dissenting).

25. Rapaczynski, supra note 21, at 396; see also THE Federalist No. 17 (A. Hamilton).

26. "Participation is likely to be more frequent, and exercised at inore different stages of a governmental activity at the local level, or in regional organizations, than at the state and federal levels. [Additionally,] the proportion of people actually involved from the total population tends to be greater, the lower the level of government, and this, of course, better approximates the citizen participation ideal." ACIR [Advisory Comm'n. on Intergovernmental Relations], Citizen Participation in the American Federal System 95 (1979).

Garcia, 469 U.S. at 575 n.18 (Powell, J., dissenting) (citation in original).

27. See, eg., FERC, 456 U.S. at 787-88 \& n.19 (O'Connor, J., concurring and dissenting); Bogen, Usery Limits on National Interest, 22 ARIz. L. REv. 753, 758-59 (1980); Goldberg-Ambrose, The Protective Jurisdiction of the Federal Courts, 30 UCLA L. REv. 542, 599 (1983); Rapaczynski, supra note 21, at 396. 


\section{Government Efficiency}

Achieving efficiency in government is another fundamental reason for the federalist system of government. ${ }^{28}$ The Framers of the Constitution believed that states could govern more efficiently because local political officials would be more familiar with the special needs of local and diverse populations. Madison noted to the Constitutional Convention that the federal government "could not extend its care to all the minute objects which fall under the cognizance of the local jurisdictions."29 Dean Choper has summarized the behefs of the Framers in this way:

[A] single, remote national government would inore than likely possess neither the systematic knowledge of local conditions nor the flexibility required for wise administration, whereas heterogeneous state government institutions would not ouly function on a more manageable scale but would encourage political experimentation and innovative response to arising social needs. ${ }^{30}$

As other commentators have observed, political theorists from de Tocqueville to Brandeis have also posited that there is "greater efficiency [in] having collective decisions inade in the smallest feasible political units." 31 These efficiency considerations led Frankfurter and Shulman to observe, "Federalism is one of the great devices to which the restless modern world turns for reconciling stability with vitality among diverse elements within a pohtical society scattered over wide territory."32

\section{Creative Experimentation}

The opportunity for creative experimentation in economic, social,

28. See generally J. ChOPER, supra note 21 , at $247-49$ and the sources collected therein. As Justice Powell has recently argued:

The Framers recognized that the most effective democracy occurs at local levels of government, where people with first hand knowledge of local problems have more ready access to public officials responsible for dealing with them. E.g.. The Federalist No. 17, p. 107 (J. Cooke ed. 1961); The Federalist No. 46, p. 316 (J. Cooke ed. 1961). This is as true today as it was when the Constitution was adopted.

Garcia, 469 U.S. at 575 n.18 (Powell, J., dissenting) (citations in original).

29. 1 THE ReCORDS OF THE FEDERAL CONVENTION of 1787 at 357 (M. Farrand ed. 1911).

30. J. CHOPER, supra note 21 , at 248.

31. See J. Buchanan \& G. Tullock, The Calculus of Consent 113-15 (1962).

32. F. Frankfurter \& H. Shulman, Cases and Other authorities on Federal JuRisdiction AND Procedure ix (rev. ed. 1937). Dean Choper notes that:

Brandeis, perhaps the most fervent twentieth-century intellectual federalist, founded his views, in Felix Frankfurter's words, "on deep convictions regarding the manageable size for the effective conduct of human affairs and the most favorable conditions for the exercise of wise judgment. ... As to matters not obviously of common national concern, thereby calling for a centralized system of control, the States have a localized knowledge of details, a concreteness of interest and varieties of social policy, which ought to be allowed tolerant scope."

J. CHOPER, supra note 21, at 248-49 (quoting Frankfurter, Mr. Justice Brandeis and the Constitution, in MR. Justice Brandeis 84-85 (F. Frankfurter ed. 1932)). 
and political ideas has often been recognized as a benefit of federahism. ${ }^{33}$ In Justice Brandeis's words, "It is one of the happy incidents of the federal system that a single courageous State may, if its citizens choose, serve as a laboratory; and try novel social and economic experiments without risk to the rest of the country." ${ }^{34}$ Recently, in Garcia ${ }^{35}$ the Court emphasized the experimentation value of federahism to help justify its reversal of Usery $:^{36}$

The essence of our federal system is that within the realm of authority left open to them under the Constitution, the States must be equally free to engage in any activity that their citizens choose for the common weal, no matter how unorthodox or unnecessary anyone else-including the judiciary-deems state involveinent to be. ... "The science of government ... is the science of experiment" ... and the States cannot serve as laboratories for social and economic experiment ... if they must pay an added price when they meet the changing needs of their citizenry by taking up functions that an earlier day and a different society left in private hands. ${ }^{37}$

The opportunity for creative experimentation, innovation, and invention is probably most important in economic activity. Economies are dynamic and change is often fast paced, particularly in an era of global markets and imcreased international trade. Economic federalism perimits states to respond rapidly and in a variety of ways to perceived market and regulatory needs. ${ }^{38}$

\section{Diffusion of Power}

The Framers of the Constitution sought to prevent the "tyranny" of a centralized government. ${ }^{39}$ The federalist structure was designed to diffuse political power by making the states independent and viable political entities. As Justice Powell observed:

The Framers believed that the separate sphere of sovereignty reserved to the States would ensure that the States would serve as an effective "counterpoise" to the power of the Federal Government. The States would serve this essential role because they would attract and retain the loyalty of their citizens. The roots of such loyalty, the Foun-

33. Justice O'Connor articulated this value in FERC. Declaring that "state innovation is no judicial myth," she cited several instances of significant state experimentation and invention. 456 U.S. at 788-89 (O'Connor, J., concurring and dissenting).

34. New State Ice Co. v. Liebmann, 285 U.S. 262, 311 (1932) (Brandeis, J., dissenting).

35. 469 U.S. 528 (1985).

36. 426 U.S. 833 (1976).

37. 469 U.S. at 546 (citations omitted); see also Community Communications Co. v. City of Boulder, 455 U.S. 40, 67 (1982) (Rehnquist, J., dissenting).

38. The laboratory-of-experiment argument for federalism is discussed and critiqued in Rapaczynski, supra note 21, at 408-14.

39. See Rapaczynski, supra note 21, at 380-95. 
ders thought, were found in the objects peculiar to state government. ${ }^{40}$

The Parker court understood and appreciated these federalism values. They give content to Chief Justice Stone's reference to a "dual system of government" 41 as the basis for the state action exemption and help explain the Court's willingness to defer to the considered economic decisions of states $m$ cases in which there is no clearly expressed congressional intent to occupy the field.

Federalism values also play an important role in the modern state action doctrine articulated in the Hoover-Hallie-SMC trilogy. ${ }^{42}$ Indeed, as I will argue later, ${ }^{43}$ the citizen participation value in particular may help explain why the Court treats delegations of regulatory authority to governmental umits more leniently than delegations to private parties. However, for a period of time between Parker and the trilogy, the Court's state action opimions seemed to shift focus fron federalism values to the national pohicy of competitive markets enibodied in the antitrust laws.

II

\section{The State Action Doctrine in Transition}

After the Parker decision, the Court did not return to the state action doctrine until $1975 ;^{44}$ it then spent the following decade reforinulating the doctrine. During this period the Court sought-at the expense of the federalism values that underlay Parker-to strengthen the role of national antitrust pohicy. ${ }^{45}$ The Court created standards for achieving state action exeinption that were extremely difficult for states to meet. While these doctrinal developments have now been largely supplanted by the Court's recent trilogy of cases, an understanding of this period highhights the dramatic nature of the Court's recent changes.

\section{A. Flirtation with Substantive Review}

In Cantor v. Detroit Edison ${ }^{46}$ the Court denied a state action exemption for a private electric utility's "free" hight bulb exchange program. The Michigan Public Service Commission had approved the tie-in as part of the utility's mandatory rate structure. Notwitlistanding agency

40. Garcia, 469 U.S. at 571 (Powell, J., dissenting).

41. Parker, 317 U.S. at 351.

42. Town of Hallie v. City of Eau Claire, 471 U.S. 34 (1985); Southern Motor Carriers Rate Conf., Inc. v. United States, 471 U.S. 48 (1985); Hoover v. Ronwin, 466 U.S. 558 (1984).

43. See infra text accompanying notes 142-44.

44. Goldfarb v. Virginia State Bar, 421 U.S. 773 (1975).

45. See cases cited supra note 8. Except for Bates, a state action exemption was always denied. Even in Bates the state's victory was somewhat hollow because the disputed regulatory actionrestraints upon attorney advertising - was found to violate the first amendment. 433 U.S. at 384.

46. 428 U.S. 579 (1976). 
approval, the Court found that the "State's policy is neutral on the question whether a utility should, or should not, have such a program.."47 The statute creating the Commission neither referred to light bulbs nor suggested that the state desired regulation of that market. ${ }^{48}$

Had the Court stopped at this point, the opinion would have been an unexceptional examination of the state's intention to supplant competition. The Court went further, however, adding that the program was not "necessary in order to inake the regulatory Act work." 49 This new inquiry invited substantive review of state regulation, as the Court then deinonstrated when it found that "there is no reason to believe that Michigan's regulation of its electric utilities will no longer be able to function effectively. Regardless of the outcome of this case, Michigan's interest in regulating its utilities' distribution of electricity will be almost entirely unimpaired."so

The Court borrowed this method of analysis from a line of cases reconciling conflicts between the antitrust laws and other federal statutes and regulations. ${ }^{51}$ By iniporting this methodology into state action analysis, the Court lost sight of the federalism concerns central to the doctrine.

In his concurrence in Cantor, Justice Blackmun also embraced substantive review by advocating an approach that would balance state and federal interests in order to determine whether the benefits of the state's regulatory scheme outweighed the anticompetitive harms to the national economy. Justice Blackmun's approach would have the Court distimguish between good and bad regulation and conduct a "searching review" to seek out more reasonable alternatives to a state's regulatory regime. $^{52}$

The Court's approach displays considerably less deference to state economic choices than the Parker Court was willing to give. As Justice Stewart warned in dissent, "[T]he Court is adopting an imterpretation of the Sherman Act which will allow the federal judiciary to substitute its judgment for that of state legislatures and administrative agencies with respect to ... anticompetitive regulatory provisions . . .."s3

\footnotetext{
47. Id. at 585 .

48. Id. at 584 .

49. Id. at 597-98.

50. Id. at 598.

51. The "implied repeal" standard is developed in Gordon v. New York Stock Exch., 422 U.S. 659, 683-85 (1975) and Silver v. New York Stock Exch., 373 U.S. 341, 357 (1963). The Court's use of the doctrine in the state action context is persuasively critiqued in Justice Stewart's dissent, 428 U.S. at 629-30; see also, Handler, Antitrust-1978, 78 CoLUM. L. REv. 1363, 1378 (1978).
}

52. 428 U.S. at $611-12$ (Blackmun, J., concurring).

53. Id. at 630 (Stewart, J., dissenting). 


\section{B. Rigorous Process Review}

After Cantor, the Court retreated from substantive review and settled instead upon a rigorous process-oriented test for determining whether state or local anticompetitive regulations qualified for the state action immunity. California Retail Liquor Dealers Association v. Midcal Aluminum, Inc. ${ }^{54}$ established the following requirement for state action immunity: "First, the challenged restraint must be one clearly articulated and affirmatively expressed as state policy; second, the policy must be actively supervised by the State itself."5s This two pronged test is process-oriented because it focuses on the mechanics that produce an anticompetitive regulation, rather than on the desirability of the regulation. ${ }^{56}$ The test was also applied rigorously: in several cases the Court closely scrutinized the requirements of each prong, with the result that state or municipal regulations were regularly invalidated..$^{57}$

The strictness of the "clear articulation" prong is illustrated by Community Communications Co. v. City of Boulder. ${ }^{58}$ There the Court was called upon to decide whether the city of Boulder, pursuant to broad "home rule" authority granted by the state constitution, was entitled to state action immunity for its anticompetitive regulation of cable television. Citing Parker, the Court stated that "[o]urs is a "dual system of government,' which has no place for sovereign cities."59 Therefore, in order for a city to meet the requirement of the first prong, it must demonstrate that the state has clearly articulated and affirmatively expressed its intention that the city inay supplant coinpetition and regulate in a particular area. Boulder failed to ineet this requirement because the Court beheved that the hoine rule authority merely expressed the state's neutrality concerning the regulation of cable television: "A State that allows its municipahities to do as they please can hardly be said to have "contemplated' the specific anticompetitive actions for which municipal liability is sought." 60 The Court declined to decide whether the active state supervision prong of the Midcal test apphed to mumicipalities. ${ }^{61}$

In the Midcal case itself the Court found no problem with the clear articulation requirement, holding that California's legislation regulating the price of wine "is forthrightly stated and clear in its purpose to permit

54. 445 U.S. 97 (1980).

55. Id. at 105 (internal quotations and citations omitted). This two prong test was first articulated in the pluraliy opinion in City of Lafayette v. Louisiana Power \& Light Co., 435 U.S. 389, 410 (1978).

56. Eule, Laying the Dormant Commerce Clause to Rest, 91 YALE L.J. 425, 439 (1982).

57. See, e.g., Boulder, 455 U.S. 40 (1982); Midcal, 445 U.S. 97 (1980).

58. 455 U.S. 40 (1982).

59. Id. at 53 (citation omitted).

60. Id. at 55 .

61. Id. at $51 \mathrm{n} .14$. 
resale price maintenance." ${ }^{.62}$ But Midcal demonstrates the difficulty a state might face from the second prong of the test. The Court held that the state's program failed the active state supervision prong:

The State simply authorizes price setting and enforces the prices established by private parties. The State neither establishes prices nor reviews the reasonableness of the price schedules; nor does it regulate the terms of fair trade contracts. The State does not monitor market conditions or engage in any "pointed reexamination" of the program. ${ }^{63}$

The Court emphasized that "[t]he national policy in favor of competition cannot be thwarted by casting such a gauzy cloak of state involveinent over what is essentially a private price-fixing arrangement." 64 Since the state was not actively involved in the anticompetitive activity, the Court viewed the activity as essentially private, and thus not entitled to state action immunity.

To be sure, when the state does not act directly but instead delegates regulatory authority to mumicipalities, agencies, or individuals, the antitrust court inust decide whether particular action is that of the state (though a delegee) or merely private activity masquerading as official state action. But the Court's willingness to apply the rigorous requirements of the process test to invalidate state attempts to delegate economic decisionmaking to agencies, mumicipalities, or individuals, narked a clear retreat froin the principles of economic federalism underpinning Parker. Although not as openly defiant as the substantive review called for by Cantor, the rigorous process test invited courts to intrude into state legislative processes to determine whether the words of a statute or its legislative history could justify a state action exemption. The test itself never specified exactly the manner in which a state must articulate its regulatory pohicies or precisely how clear the articulation inust be. As a result, a federal antitrust court had wide latitude to divine wliat the state intended by its regulatory laws and whether delegees acting under those laws were acting within the proper scope of the state's authority. ${ }^{65}$ The possibility of such free-wheeling inquiry prompted a warning froin Justice Stewart: "[S]tate statutes often are enacted with hittle recorded legislative history, and the bare words of a statute will often be unilluminating in interpreting legislative intent. . . . Without legislative history or relevant statutory language, any answer to [wliat the legislature

62. 445 U.S. at 105.

63. Id. at 105-06.

64. Id. at 106.

65. Federal courts are usually reluctant to engage in this type of inquiry. See 1 P. AREeDA \& D. TURner, ANTITRUST LAW $\S 214 \mathrm{a}$, at 81 (1978); Wiley, A Capture Theory of Antitrust Federalism, 99 HARV. L. REv. 713, 736 (1986). 
'contemplated'] would be purely a creation of judicial imagination."66

The difficulty of evaluating state regulatory schemes under the clear articulation standard was further compounded by language in Goldfarb v. Virginia State $\mathrm{Bar}^{67}$ stating, "It is not enough that . . . anticompetitive conduct is 'prompted' by state action; rather, anticompetitive activities must be compelled by the direction of the State acting as a sovereigu." But the Court never spelled out what would constitute coinpulsion. The Court also failed in Midcal to clarify whether Goldfarb's compulsion requirement was supplanted by Midcal's two-pronged test, or whether the clear articulation prong incorporated the compulsion eleinent. ${ }^{69}$

The rigorous process test thus inade it more costly and difficult for states to delegate regulatory authority "correctly."70 Moreover, even agencies, municipalities, and individuals actually possessing "legally" delegated regulatory authority (that is, delegations meeting the Midcal requirements) could be reluctant to use it: the lack of clarity in the legal standards for state action immunity, the uncertainty about how the standards would be apphed, ${ }^{71}$ and the threat of treble damage hability ${ }^{72}$ could still be expected to chill even the legitinate exercise of regulatory authority.

During this period, the Court routinely acknowledged the federalism rationale of Parker, ${ }^{73}$ but language in the Court's opinions-and certainly the results of applying the rigorous process test-suggest that the Court considered the positive values of antitrust nore important than those of econoumic federahism. The Court lauded the "regime of competition" promoted by the antitrust laws as "the fundamental principle gov-

66. City of Lafayette v. Louisiana Power \& Light Co., 435 U.S. 389, 437 (1978) (Stewart, J., dissenting).

67. 421 U.S. 773 (1975).

68. Id. at 791 (emphasis added).

69. This issue was resolved when the Court firmly rejected a compulsion requirement in Town of Hallie v. City of Eau Claire, 471 U.S. 34, 46-47 (1985) and SMC, 471 U.S. at 61.

70. The transaction costs of government increase and flexibility is sacrificed. See Lafayette, 435 U.S. at 438 (Stewart, J., dissenting); Areeda, Antitrust Immunity for "State Action" Afler Lafayette 95 HARV. L. REv. 435, 439 (1981); Wiley, supra note 65, at 733-34.

71. Congress perceived this problem when it condidered passage of the Local Government Antitrust Act, 15 U.S.C.A §§ 34-36 (West Supp. 1986). See H.R. REP. No. 965, 98th Cong., 2d Sess. 7, reprinted in 1984 U.S. CODE CONG. \& ADMIN. NEwS 4602, 4608 ("The Court is open to criticism perhaps not so much for the results it has reached in individual [state action] cases, but rather for its failure to provide an analytical framework by which future state action cases can be predicted with reasonable certainty."), quoted in Wiley, supra note 65, at 736 n.111.

72. For cities, this fear was alleviated by the Local Government Antitrust Act, which provided that "[n]o damages, interest on damages, costs or attorney's fees may be recovered" by private plaintiffs suing local governments or officials. 15 U.S.C.A. $\S \S 35,36$ (West Supp. 1986). Equitable relief is still available, however. See $i d . \S 26$. Congress passed the "Boulder Bill" in response to the outcry from municipalities following the Boulder decision. Treble damages, however, are still possible in suits involving direct state action or state agency delegations to private parties.

73. See, e.g., Lafayette, 435 U.S. at 400; Boulder, 455 U.S. at 53. 
erning commerce in this country,"74 and "the polestar by which all must be guided in their business affairs."75 The Court emphasized that it "could not accept the view that the federal interest inust inevitably be subordinated to the State's" ${ }^{376}$ and worried that municipal regulations had the potential seriously to distort "the ratioual and efficient allocation of resources, and the efficiency of free markets which the regime of competition enbodied in the antitrust laws is thought to engender."77

The Parker Court had also understood the importance of federal antitrust pohicy and recognized that state economic regulation might supplant competition and free markets. But Parker nonetheless gave states room to establish economic and regulatory policy. What seems to have changed during the period after Parker is the Court's attitude toward economic federalism. Unfortunately, the Court lias made no effort to explain its shift in emphasis. ${ }^{78}$

The Court's tilt toward federal antitrust pohicies and its willingness to intervene in state economic affairs did not occur without dissent. In Justice Rehnquist's view, "The Parker doctrine correctly holds that the federal interest in protecting and fostering competition is not infringed so long as the state or local regulation is so structured to ensure that it is truly the government, and not the regulated private entities, which is

74. Lafayette, 435 U.S. at 398.

75. Id. at 406 .

76. Cantor v. Detroit Edison Co., 428 U.S. 579, 595 (1976).

77. Lafayette, 435 U.S. at 408.

78. It is tempting to speculate about the causes of the Court's shift. For example, the Court's willingness to engage in heightened scrutiny of state action before granting an exemption from the antitrust laws corresponds to a period during which the Court showed a marked increase in confidence in its ability to conduct sophisticated economic analysis in antitrust cases in order to separate efficient and procompetitive behavior from anticompetitive conduct. See, e.g., Continental T.V. v. GTE Sylvania, 433 U.S. 36 (1977); Broadcast Music, Inc. v. Columbia Broadcasting Sys., 441 U.S. 1 (1979).

Professor John Wiley has recently speculated that the change in the state action doctrine can be explained by a "capture" theory of regulation:

[T]his doctrinal shift has paralleled a theoretical shift in conceptions of the nature of regulation itself. Parker reflected a New Deal confidence in market regulation. . . A A growing suspicion that producers have "captured" the political bodies regulating them has inclined people to view regulation as the product and protector of producer interests. ... Thus, it is hardly surprising that courts have, under the guise of the very state action doctrine that was meant to protect state sovereiguty, intruded more and more on state and local regulatory policy.

Wiley, supra note 65 , at 714 .

None of the Court's opinions, however, refers to the possibility of regulatory capture as a cause of the Court's reformulation of the state action doctriue. More significantly, Wiley does not appear to recognize that the Hoover-Hallie-SMC trilogy returns the state action doctrine to its federalisin roots and drainatically reduces the opportunity for federal court intrusion into state affairs. Were the Court concerned with regulatory capture, it would not have crafted its new, lenient process standard of review for state action. See Garland, Antitrust and State Action: Economic Efficiency and Political Process, 96 YALe L.J. 486, $490-93$ (1987). 
replacing competition with regulation."79 "The Sherman Act," he warned, "should not be deemed to authorize federal courts to "substitute their social and economic beliefs for the judgment of legislative bodies, who are elected to pass laws.' . . . The federal courts have not been appointed by the Sherman Act to sit as a 'superlegislature to weigh the wisdom of legislation." "B0 Moreover, Congress quickly stepped in after Boulder to aid municipalities by passing the Local Government Antitrust Act. ${ }^{81}$ As a result, even when a local government could not convince a court that the challenged regulation was within the state action exemption, it no longer had to fear the possibility of treble damage antitrust hability.

\section{III}

The New State Action Doctrine: Deferential ECONOMIC FEDERALISM

In the recent Hoover-Hallie-SMC trilogy, the Court clarified the state action doctrine and returned it to its federahism roots. ${ }^{82}$ The Court held that when a sovereigu state acts directly, the state action exemption applies ipso facto. For the remaining instances in which a state delegates regulatory authority to a municipality, state agency, or individuals, the Court modified the Midcal test to require only a lenient process review.

\section{A. Ipso Facto Exemption When the Sovereign Acts Directly}

Parker created the state action exemption in the context of direct action by the sovereign; the California state legislature itself had enacted the statute that restricted competition among raisin producers. In Hoover ${ }^{83}$ the Court took note of this and observed that "under the Court's rationale in Parker, when a state legislature adopts legislation, its actions constitute those of the State ... and ipso facto are exempt from the operation of the antitrust laws." ${ }^{94}$

Hoover involved direct action taken by the Arizona Supreme Court in refusing the plaintiff admission to the state Bar. The Arizona Constitution gave the supreme court plenary authority to determine admissions to the Bar. The supreme court appointed a committee to help screen applicants by administering and grading a bar examination. Plaintiff alleged that the grading formula adopted by the cominittee restrained

79. Boulder, 455 U.S. at 70 (Rehnquist, J., dissenting).

80. Id. at 68 (citations omitted). Justice Stewart made similar points in Cantor, 428 U.S. at 627,640 (dissenting opinion).

81. See supra notes 71-72.

82. See cases cited supra note 42.

83. 466 U.S. 558 (1984).

84. Id. at 567-68 (citations omitted). 
coinpetition by artificially limiting the number of lawyers who could practice in Arizona. The Court, however, found that the committee was advisory only and that "[t]he action at issue here, whether anticompetitive or not, clearly was that of the Arizona Supreme Court." 85 Thus, the action denying plaintiff admission to the bar was by the sovereign itself and ipso facto exempt from the antitrust laws.

As the Court explained:

The reason that state action is immune from Sherman Act liability is not that the State has cliosen to act in an anticompetitive fashion, but that the State itself has closen to act. . . The Court did not suggest in Parker, nor has it suggested smce, that a state action is exempt from antitrust hability only if the sovereign acted wisely after full disclosure from its subordinate officers. The only requirement is that the action be that of "the State acting as sovereign." 86

Furthermore, the Court pointed out that when the sovereign acts directly, "the danger of unauthorized restraint of trade does not arise." Thus the need to "address the issues of 'clear articnlation' and 'active supervision" " is obviated. ${ }^{87}$

Parker involved direct action by a state legislature and Hoover involved direct action by a state supreme court. Whether ipso facto exemption is also to be accorded the direct actions of a state governor is a question expressly reserved in Hoover. ${ }^{88}$ However, in view of the Court's renewed deference to state sovereign actions, it is probable that the Court will answer that question affirmatively when the occasion arises. ${ }^{89}$

\section{B. Lenient Process Review When the Sovereign Delegates Regulatory Authority}

Almost all state regulation is conducted by mumicipalities, state agencies, or private parties under the delegated authority of the state. In Hallie and SMC, the Court clarified the legal standards that these "nonsovereign state representative[s]" 90 would have to meet in order to qual-

85. Id. at 574 .

86. Id. (citations omitted).

87. Id. at 569. The dissenters argued strongly that the action was that of the committee (not the soveriegn itself) and that there was inadequate delegation of authority. Id. at 588-89, 599 (Stevens, J., dissenting).

88. Id. at 568 n.17.

89. Cf. Deak-Perera Hawaii, Inc. v. Department of Transp., 745 F.2d 1281 (9th Cir. 1984), cert. denied, 470 U.S. 1053 (1985). In Deak-Perera, the Ninth Circuit applied Hoover's reasoning and extended state action exemption to executive branch actions of the Hawaii Department of Transportation. Id. at $\mathbf{1 2 8 3}$. The opinion raises difficult questions concerning the scope of ipso facto exemption. It is one thing for the governor to act directly and receive ipso facto exemption from the antitrust laws, but perhaps something quite different when an executive agency, department, or other entity acts. These bodies may be analytically closer to state agencies and hence should have their actions evaluated under the standards set forth in SMC. See infra text accompanying notes 116-25.

90. The Court used this term in Hoover, 466 U.S. at 569 (1984). 
ify for state action immunity from the antitrust laws. The basic elements of the Midcal test were retained, but were refined in a manner that plainly reduced the rigor of the Court's scrutiny. The result is a judicially administrable test that promises greater deference to state economic choices and a return to the values of economic federalism.

\section{The Clear Articulation Requirement}

This prong of the Midcal test remains the most important and is applicable to all state agents exercising regulatory authority. ${ }^{91}$ In Hallie the Court acknowledged tliat earlier cases had never "fully considered precisely how clearly a state policy must be articulated . . . to establish that [an] anticompetitive activity constitutes state action." 92 To remedy this defect, the Court lield that a state statute need not explicitly indicate legislative intent to supplant competition with regulation..$^{93}$ Rather, it is sufficient if a reading of the statute indicates that it "clearly contemplate[s]"94 anticompetitive activity, or that such conduct is a "foreseeable" 95 or "logical"96 result of the authority delegated. And while authorization must be more specific than a general "home rule" grant, sucl as that involved in Boulder, ${ }^{97}$ reference in the authorizmg statute to a field or area of authority, sucl as the provision of sewer services in Hallie $^{98}$ or the regulation of trucking rates in $S M C{ }^{99}$ is sufficient.

In relaxing the clear articulation requirement, the Court also made

91. Id. at 568-69.

92. 471 U.S. at 40.

93. Id. at 42 " "It is not necessary ... for the state legislature to have stated explicitly that it expected the City to engage in conduct that would have antieompetitive effects." (citing New Motor Vehicle Bd. v. Orrin W. Fox Co., 439 U.S. 96, 109 (1978) and 1 P. AREEDA \& D. TURNER, ANTrTRUST LAw If 212.3, at 54 (Supp. 1982))); SMC, 471 U.S. at 64 ("A private party acting pursuant to an anticompetitive regulatory program need not 'point to a specific, detailed legislative authorization' for its challenged conduct." (citation omitted)).

94. Hallie, 471 U.S. at 42.

95. Id.

96. Id.

97. 455 U.S. 40 (1982). In Boulder the Court held that a grant of home rule authority to the city by the state constitution was not specific enough a delegation from the State to warrant a state action exemption from the antitrust laws: "A State that allows its municipalities to do as they please can hardly be said to have 'contemplated' the specific anticompetitive actions for which municipal liability is sought." Id. at 55; see also the discussion of Boulder in Hallie, 471 U.S. at 43.

98. 471 U.S. at 43 ("Here, in contrast [to the home rule authority in Boulder], the State has specifically authorized Wisconsin cities to provide sewage services and has delegated to the cities the express authority to take action that foreseeably will result in anticompetitive effects.").

99. Therefore, we hold that if the State's intent to establish an anticompetitive regulatory program is clear, as it is in Mississippi [citing statute authorizing the public service commission to prescribe rates for motor common carriers], the State's failure to describe the implementation of its policy in detail will not subject the program to the restraints of the federal antitrust laws.

471 U.S. at $64-65$. 
clear that "compulsion" was not necessary for state action exemption. ${ }^{100}$ Distmguishing Goldfarb, ${ }^{101}$ the Court held that "a state policy that expressly permits, but does not compel, anticompetitive conduct may be 'clearly articulated' within tlie meaning of Midcal."102 The Court recognized that "compulsion affirmatively expressed may be the best evidence of state policy," but it is not a prerequisite to a finding of state action. ${ }^{103}$ The Court rejected a compulsion requirement because it would exact too high a toll on both the principles of economic federalism and the goals of antitrust:

The Parker doctrine represents an attempt to resolve conflicts that may arise between principles of federalism and the goal of the antitrust laws, unfettered competition im the marketplace. A compulsion requirement is inconsistent with both values. It reduces the range of regulatory alternatives available to the State. At the same time, imsofar as it encourages States to require, rather than merely permit, anticompetitive conduct, a compulsion requirement may result in greater retramts on trade. We do not beheve that Congress intended to resolve conflicts between two competing interests by impairing both more than necessary. ${ }^{104}$

These modifications $i m$ the clear articulation prong of the Midcal test make it much easier for states to delegate regulatory autliority without running afoul of the antitrust laws. Indeed, the Court's application of the standard in Hallie demonstrates low extraordmarily lement the process review has become. In Hallie, Wisconsm statutes authorized cities to estabhsh sewage systems and to "delmeate the area within which service will be provided." 105 Pursuant to this statute, the City of Eau Claire constructed a sewage treatment facility and refused to provide sewage treatment services to four neigliboring townships unless they agreed to take sewage collection and transportation services as well. The four towns brought an antitrust suit for injunctive relief, claiming tliat the City was unlawfully tying sewage collection and transportation to

100. Id. at 60. The Court also expressly rejected the dissent's effort to return to Cantor's substantive approach of limiting Parker immumity to only those cases in which an antitrust exemption is "necessary . . . to make the [program] work." Id. at 57 n.21.

101. 421 U.S. 773, 790. In Goldfarb, the Court used language that suggested a compulsion requirement. In $S M C$, however, the Court retreated from this position: "Goldfarb . . . is not properly read as making compulsion a sine qua non to state action immunity. . . Although Goldfarb did employ language of compulsion, it is beyond dispute that the Court would have reached the same result had it applied the two-pronged test later set forth in Midcal." 471 U.S. at $60-61$.

102. SMC, 471 U.S. at 61 .

103. Hallie, 471 U.S. at 45-46. See also SMC, 471 U.S. at $61-62$ ("Our holding today does not suggest, however, that compulsion is irrelevant. To the contrary, compulsion often is the best evidence that the State has a clearly articulated and affirmatively expressed policy to displace competition." (citations omitted)).

104. SMC, 471 U.S. at 61 .

105. 471 U.S. at 41 , citing W1S. STAT. ANN. $\$ 66.069(2)(e)$ (West Supp. 1984). 
sewage treatment. Although the statutes said nothing about tying the provision of one aspect of sewage services to another, the Court held that the statutory authority to delineate service areas "clearly contemplate[s] that a city may engage in anticompetitive conduct. ... We think it is clear that anticompetitive effects logically would result from this broad authority to regulate." 106

In short, the key factor for state action immunity is whether a state legislature has delegated regulatory authority in a general subject area, like sewage services. Once the subject area has been delegated, the Court is prepared to use its imagination liberally in determining whether particular anticompetitive conduct was a foreseeable or logical result of the regulatory delegation.

Requiring any greater degree of statutory authorization, the Court said in Hallie, would "enbod[y] an unreahistic view of how legislatures work and of how statutes are written. No legislature can be expected to catalog all of the anticipated effects of a [regulatory] statute . . ."107 Borrowing from Justice Stewart's dissent in Lafayette, the Court worried that "requiring [more] explicit authorization by the State inight have deleterious and unnecessary consequences. ... with detrimental side effects upon inunicipalities' local autonomy and authority to govern theinselves."108 Furthermore, the Court recognized that a more lenient standard of review would obviate the need for detailed interpretation of state statutes, a central problem in rigorous review. ${ }^{109}$

\section{The Active Supervision Requirement}

Midcal's second prong requires the state to supervise actively the anticoinpetitive conduct of private parties who have been delegated regulatory authority. ${ }^{10}$ The Court, however, did not specify the type and

106. Hallie, 471 U.S. at 42 (citations omitted).

107. Id. at 43.

108. Id. at 44 , citing Lafayette, 435 U.S. at $434-35$ (Stewart, J., dissenting). The Court expressed similar concerns in SMC:

If more detail than a clear intent to displace competition were required of the legislature, States would find it difficult to implement through regulatory agencies their anticompetitive policies. Agencies are created because they are able to deal with problems unforeseeable to, or outside the competence of, the legislature. Requiring express authorization for every action that an agency might find necessary to effectuate state policy would diminish, if not destroy, its usefulness.

471 U.S. at 64.

109. Hallie, 471 U.S. at 44 n.7:

Requiring such a close examination of a state legislature's intent to determine whether the federal antitrust laws apply would be undesirable also because it would embroil the federal courts in the unnecessary interpretation of state statutes. Besides burdening the courts, it would undercut the fundamental policy of Parker and the state action doctrine of immunizing state action from federal antitrust scrutiny. See 1 P. AREEDA \& D. TURNER, ANTITRUST LAW, ๆ 212.3(b) (Supp. 1982).

110. See supra text accompanying notes $49-52$. 
amount of supervision required. Of even greater importance, Midcal did not resolve whether the state must also actively supervise the delegated regulatory behavior of cities and agencies $m$ order to secure state action immuinty for their actions. The plurality opmion in Lafayette had suggested that such a requirement might apply to mumicipalities, ${ }^{111}$ but Boulder expressly reserved the question. ${ }^{12}$

Addressing these ambiguities in Hallie, the Court confessed "It is fair to say that our cases have not been entirely clear." 113 The Court then stated flatly that the active supervision requirenent "should not be imposed in cases in which the actor is a municipality."114 In a footnote, the Court continued, "In cases in which the actor is a state agency, it is likely that active state supervision would also not be required, although we do not here decide that issue."115

With respect to anticompetitive conduct by private parties, the Court reaffirmed that " $[\mathrm{w}]$ here state or mumcipal regulation of a private party is involved, however, active state supervision must be shown, even where a clearly articulated state policy exists."116 The facts of SMC, however, indicate that the required supervision need not be intense. In $S M C$, the statutes of four states permitted motor common carriers to submit collective rate proposals to the state public service commissions. Proposed rates would become effective if the agency failed to act within a specified time. If the agency scheduled a hearing, it would then have to approve the rates formally. ${ }^{117}$ Even though the agency liad the option to be only passively mvolved in ratemaking, the government conceded that this level of involvement satisfied the active supervision prong of the Midcal test. ${ }^{118}$ The Court found it siguificant that " $[t]$ he State Public Service Commissions thus have and exercise ultimate authority and control over all imtrastate rates." 119

The Court justified imposing lighter requirements on governmental units than on private actors by focusing upon the public character and openness of regulation by a unit of government. In Hallie, the Court said "We may presume, absent a slowing to the contrary, that [a] mumicipality acts in the public interest." 120 More specifically, the Court noted:

Among other things, mumicipal conduct is mvariably more likely to

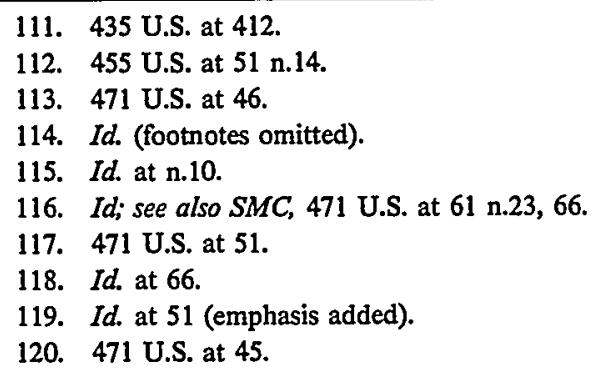


be exposed to public scrutiny than is private conduct. Municipalities in some states are subject to "sunshine" laws or other mandatory disclosure regulations, and municipal officers, unlike corporate heads, are checked to some degree through the electoral process. Such a position in the public eye may provide some greater protection against antitrust abuses than exists for private parties. ${ }^{121}$

Thus, the Court saw no need for more than a clear articulation of state policy to exenıpt municipal activity. ${ }^{122}$

The Court did not believe, however, that the conduct of private parties acting under government regulation should be entitled to a public interest presumption, even when a state or municipality has clearly delegated the authority to act. The Court noted that "[w]here a private party is engaging in the anticompetitive activity, there is a real danger that he is acting to further his own interests, rather than the governmental interests of the State."123 Thus, in the Court's view, when private parties are involved, ${ }^{124}$ the active supervision requirement is needed because it "prevents States fron1 'casting . . . a gauzy cloak of state involvenient over what is essentially a private price-fixing arrangement'. . . [ [and] ensures that a state's actions will immunize the anticonipetitive conduct of private parties only when the 'state has demonstrated its commitment to a program through its exercise of regulatory oversight.' "'125

In 324 Liquor Corp. v. Duffy, ${ }^{126}$ the Court recently reaffirmed the importance of the active supervision requirement when it struck down New York's Alcohohic Beverage Control Laws requiring retailers to charge at least $112 \%$ of the posted wholesale liquor prices set by private wholesalers, but allowed the wholesalers to sell to retailers at less than the posted prices. As in Midcal, the state had clearly articulated its desire to permit vertical price fixing, a per se violation of the Sherman Act, but failed to supervise actively the price fixing process that had been delegated to private wholesalers. The Court found that "[ $t]$ he State has displaced competition among hquor retailers without substituting an ade-

121. Id. at n.9.

122. Id. at 47. As previously noted, the Court also indicated that it would probably not require active supervision of activity by a state agency, although formally the Court reserved the question. See supra text accompanying note 109 . In most circumstances, it would probably make sense to extend to state agencies the same presumption of acting in the public interest that the Court applied to municipalities. However, if a particular state agency activity is not "in the public eye" or is not open to citizen participation, the Court has wisely left itself room to treat such a case more like private activity, and thus subject to an active supervision requirement. On the importance of the opportunity for citizen participation, see infra text accompanying notes 142-44.

123. Hallie, 471 U.S. at 47.

124. The active supervision requirement applies to private party delegations fron either the state or a municipality. Id. at $46 \mathrm{n} .10$.

125. SMC, 471 U.S. at 61 n.23 (citations omitted).

126. 107 S. Ct. 720 (1987). 
quate system of regulation." 127 Thus, the requirements of the state action exemption were not met. ${ }^{128}$

IV

\section{Evaluating Deferential ECONOMIC Federalism AND THe State Action Doctrine}

\section{A. The Benefits of Lenient Process Review}

The Court's clarifications are important and welcome steps in the evolution of the state action doctrine. By lowering the requirements that a state must meet to establish state action, the Court reduces the costs and burdens of acquiring exemption from the antitrust laws, which in turn gives the states greater freedom to experiment creatively with the economic mix of competition and regulation. ${ }^{129}$ The Court thus strikes a balance between antitrust and economic federalisin values that perimits states to play an active role im the economy and that drastically reduces the instances of federal court intervention into state regulatory regimes. ${ }^{130}$

\section{The Clear Articulation Requirement}

The Court's lemient process approach to the clear articulation requirement is a significant advance over the rigorous process test. One would expect that federal court imtervention into state regulatory activity will be substantially curtailed because a state can now meet the requirement when it delegates regulatory authority for a particular type of activity or area of the economy. Greater specificity im delegation is not needed. In addition, federal courts will be more readily able to administer the current fornulation of the clear articulation requirement because it substitutes objective statutory interpretation for subjective probing of legislative intent. ${ }^{131}$ This in turn should promote predictability im this area of antitrust law. ${ }^{132}$

127. Id. at 726.

128. The Court also held that the state statutory scheme was not protected by the twenty-first amendment's grant to the states of authority to regulate liquor. Id. at 730.

129. Although Fisher v. City of Berkeley, 106 S. Ct. 1045 (1986) was not decided on state action grounds, the Conrt's holding is consistent with the deferential approach of the Hoover-Hallie-SMC trilogy because it imposes upon plaintiffs the additional burden of proving "agreement" when alleging that state and local governmental regulations are preempted by $\S 1$ of the Sherman Act. See Garland, supra note 78, at 497-98, 503-07.

130. Garland also positively assesses the Court's approach. See Garland, supra note 78.

131. See, e.g., Llewellyn v. Crothers, 765 F.2d 769, 774 (9th Cir. 1985) (indicating that "motive" for regulation is unimportant as long as the subject area of regulation was properiy delegated).

132. See Jorde, Restoring Predictability to Merger Guideline Analysis, 4 CoNTEMP. PoL'Y Issues 1, 14 (1986) (to be reprinted in The Antitrust Bulletin, Snmmer 1987):

Antitrust laws ... are an integral part of U.S. industrial policy. These laws help shape the 
Of course, one might argue that the Court did not go far enough in advancing state interests because the mere existence of a clear articulation requirement-even in lenient form-burdens federalism and imposes unnecessary costs upon the states. ${ }^{133}$ But in reality, the Court's current formulation imposes a very small price for striking a needed balance between econoimic federahsm and antitrust values. Parker requires some vehicle for separatimg state from private activity. The clear articulation requirement asks a state to indicate plainly that shielded conduct is indeed that of the state, and thus it enables a court to identify-and limit-anticompetitive conduct that is entitled to exemption on grounds of economic federalism. ${ }^{134}$ This identification and limitation is accomplished with minimal imtrusion imto state governmental processes. ${ }^{135}$ In addition, a clear articulation requirement advances the federalism value of citizen participation by insuring that governmental decisions to supplant competition with regulation are made public and thus more easily subject to review. ${ }^{136}$

\section{The Active Supervision Requirement}

The Court's clarification of the active supervision requirement is also a significant advance. By holding that the requirement applies only to delegations of regulatory authority to private parties and not governmental units, ${ }^{137}$ the Court has eliminated a major uncertainty of its own creation. ${ }^{138}$

Some critics have argued that even when the requirement is iniposed only on delegations of regulatory authority to private parties, it still subverts federalism because it requires costly command and control supervi-

structure of American industry by indicating when government will intervene to prohibit business behavior or market-structure changes that will harm competition. Ambiguity and uncertainty regarding the application of antitrnst laws may cause excessive deterrence, as business tries to steer clear of possible antitrust hability. Such excessive deterrence can be costly to the extent that it discourages efficient or innovative behavior and market structure.

(footnote omitted).

133. Wiley, supra note 65 , at $733-37$.

134. Separatimg state action from merely private conduct, of course, was the goal of Parker's state action doctrine and the basis of the Court's caution that "a state does not give immunity to those who violate the Sherman Act by authorizing them to violate it, or by declaring that their action is lawful." Parker, 317 U.S. at 351 (citation omitted).

135. Ironically, Professor Wiley, who laments the costs of even this minimal requirement, offers a substitute test that is significantly more intrusive and more difficult to administer than the clear articulation requirement. See Wiley, supra note 65 , at 743-76 (requiring courts to decide, among other things, whether a state or local regulation responds to a substantial market inefficiency, and whether the regulation is the product of regulatory capture). For a detailed critique of Wiley's approaeh, see Garland, supra note 78 .

136. Cf. Page, supra note 5 , at 1106 .

137. See supra text accompanying notes 104-19.

138. See supra text accompanying notes 49-59, 110-12. 
sion, and it limits the methods a state may employ to implement a prograin of regulation. ${ }^{139}$ Cast in the language of federalism values, such criticism expresses concern that "government efficiency" and "creative experimentation" are subverted.

The Court left itself open to such criticisin when it failed to articulate a justification for the active supervision requirement that was independent of the clear articulation requirement. The Court discussed the active supervision requirement as a means of separatimg state from private action, noting that active supervision deinonstrates a state's "commitınent" to conducting regulation through private parties. ${ }^{140}$ As the critics point out, this seems to convert the requirement into hittle more than additional evidence of a state's intention to supplant competition with regulation. ${ }^{141}$ Seen from this perspective, the active supervision requirement does indeed appear to be only a costly redundancy of the clear articulation requirement and an unnecessary interference with a state's chosen ineans of regulating.

However, the Court's requirement of active supervision of private delegations of regulatory authority can be independently justified because it promotes the citizen participation value of federahism. Left to their own devices, private parties can hardly be expected to provide the public the same opportumity to participate in a delegated regulatory decisionmaking process that can reasonably be expected of state and municipal units of government. Viewed in this hight, active supervision by a governmental unit of private delegations is needed to provide an opportunity for citizen participation, which is one of the important values justifying deference to a state's economic choices. Although the Court did not specifically nivoke the citizen participation value, it hinted at such a concern when it noted that numicipahties, not private parties, "act[ $[$ in the public interest"142 and occupy "a position in the public eye." 143

The citizen participation value of economic federalism supports deference to state decisions that are the product of meaningful public participation in the decision to supplant competition with regulation. When a state delegates regulatory authority to a subordmate governmental umit, such as a municipality or state agency, the public will generally have the opportunity to participate in any subsequent decision to exercise the delegated authority. This is readily apparent in municipal regulatory decisionmaking which is usually preceded by public hearings or other opportunities to voice opinions and concerns. Furthermore, municipal

139. See Page, supra note 5, at 1128-30; Wiley, supra note 65 , at 721, 733-36.

140. Southern Motor Carriers Rate Conf. Inc. v. United States, 471 U.S. 48, $61-62$ (1985).

141. See supra note 139.

142. Town of Hallie v. City of Eau Claire, 471 U.S. 34, 45 (1985).

143. Id. at $45 \mathrm{n} .9$. 
officials must stand election, which gives the public ultimate participation in and control of regulatory decisions.

State agencies also usually provide some opportunity to participate in decisions they make to regulate, although an agency may not function as democratically as a municipal government. In addition, agencies regularly undergo budgetary review, giving the public another opportunity to participate and voice concern about regulatory decisions. To be sure, public participation before state agencies may require heightened political awareness and some degree of expertise; even then, citizen participation may not be as effective as participation by those who are actually regulated by the agency. ${ }^{144}$ But the important point is that the opportunity to participate exists at the juncture when decisions are made to supplant competition with regulation.

There is no equivalent opportumity to participate in regulatory decisions inade by private parties, such as a state bar organization or liquor wholesalers, who have been delegated state regulatory powers. Although the public is able to participate in the imitial legislative decision to delegate regulatory autliority, that is not the critical point at whicli decisions are made about whetlier and how to supplant competition witli regulation. Requiring active supervision of delegations of regulatory authority to private parties ensures that there will be an agency structure that will provide an opportunity for the public to participate in regulatory decisions. Another benefit of active supervision is the likeliliood tliat public participation and regular review will occur at reasonable time intervals.

Admittedly, $S M C$ deinonstrates that the active supervision requirement can be met with relative ease. Rates submitted by private rate bureaus to a state public service commission become effective if the agency takes no action within a specified period of time. But as long as the agency has ultimate authority over rates, tlie active supervision requirement is discharged. The opportunities for public participation, tlierefore, may be minimal. Once rates are submitted, the public inay liave the burden of convincing the agency to liold liearings; nevertheless, the Coinmission provides a forum to hear tlie public's arguinents. By comparison, in Midcal and 324 Liquor Corp. there was no supervising state agency and lience no place for the public to seek review of the privately set liquor prices. The inportance of the participation value in economic federalisin, then, may help explain the Court's insistence that there be active supervision by a government agency in these cases.

144. See, e.g., M. Olson, The Logic of Collective Action 127-28 (2d ed. 1971); Page, supra note 5, at 111-12; Wiley, supra note 65 , at $723-25$. 


\section{B. Addressing the Costs of Deferential Economic Federalism}

While the Court's lenient process approach to the state action doctrine accords well with the values of economic federalism and with an appropriately modest role for the federal courts, deferential economic federalism also results im economic costs that may warrant serious consideration. The inost miportant of these are allocative inefficiency costs and spill-over costs. Measuring the substantiality of these and other significant costs, ${ }^{145}$ and determining the manner in which they should be taken nito account $\dot{n} 1$ a system of econonric federalisn is the next frontier of the state action doctrine. I am currently engaged in research in this area with iny colleague Dan Rubinfeld. In this Section, I will try to sketch briefly the miportant issues that must be addressed and to identify appropriate responses.

\section{Allocative Inefficiency Costs}

Coinpetitive inarkets tend to yield an efficient allocation of society's resources. Competition among firms in a market drives the price of goods and services to their inarginal cost, which permits consuiners to niake purchases at the best mix of price and quality that can be obtained in the econorny. In addition, the incentives in a coinpetitive market generate variety, innovation, and technological change. The federal antitrust laws were enacted to secure these benefits of conipetition by pohicing inarket structures and prohibiting anticoinpetitive conduct.

When states are able to supplant coinpetition with regulation, as the state action doctrine now hiberally permits, allocative inefficiencies inay result. For example, states niay directly set the price of goods and services, or may divide a market or limit entry into a market, which in turn is likely to lessen supply and allow price to rise above conipetitive levels. Such regulation causes underproduction and forces consuiners to pay "too inuch" for what they receive. Taxicab regulation and occupational licensing may be nistances of such allocatively inefficient regulation.

States and local governments inay enact allocatively inefficient regulations for a variety of reasons. They inay nnisperceive a market failure; they inay recoguize the economic costs of regulation but be willing to bear thein because they believe that regulation is necessary to acconiphish

145. In addition to (1) allocative inefficiency costs and (2) spill-over costs, economic federalism also may produce (3) diversity costs (caused by a lack of uniform standards among the states), (4) "prisoner's dilemma" costs (caused in circumstances in which governmental units would be better off if they cooperated, rather than competed, with each other), and (5) administrative inefficiency costs (caused by decisionmaking at a level of government that lacks efficiencies of scale in information gathering or that suffers from bureaucratic diseconomies of scale). See Mashaw \& RoseAckerman, Federalism and Regulation, in The ReAGan Regulatory STRATEgy 111, 115-22 (1984). 
soine other goal, such as incoine redistribution or public safety; or they may succumb to the lobbying efforts of producers who will benefit from the regulation. Whatever the reason, the result is the same: goods and services are underproduced, generating inonopoly profits for producers and higher prices for consumers. Of course, these allocative inefficiency costs may be visited only, or primarily, upon the citizens of the jurisdiction enacting the regulation. But they are still costs and they reduce the total size of the national economic pie. When the costs of allocative inefficiencies in all jurisdictions are cumulated, there is a clear national welfare loss.

This type of loss, however, is not unexpected in a system of economic federalisin that vests in the states an opportunity to determine the desired mix of coinpetition and regulation in their own economies. These costs are offset by the benefits of economic federahsin-citizen participation in government, efficiency in governinent, creative experimentation, and diffusion of power. The Parker court understood this when it crafted the state action doctrine and, apparently, so does the present Court, with its lenient process review.

Some critics have called for a change in the state action doctrine, arguing that it should only exeinpt state action that addresses real market failures, that allocatively inefficient regulation should not be exempt. ${ }^{146}$ The Court's recent trilogy, however, wisely avoids such an intrusive course into state affairs. First, such an approach elevates allocative efficiency above the benefits of economic federalism, a course of action not supported by the legislative history. Second, federal courts are as ill equipped today as they were during the Lochner era to determine whether state economic regulation is wise or necessary. ${ }^{147}$ Finally, Congress is the branch of government that should ainend the antitrust laws to reach state activities or enact new federal laws to regulate portions of the economy on a national basis. ${ }^{148}$

If Congress should decide that the balance between allocative efficiency and economic federalisin should be re-struck, then there are a number of paths that inight be taken. Congress could respond on a substantive basis by eliminating the state action doctrine and making the antitrust laws fully apphicable to the states, or by limiting the doctrine to state actions that are narrowly tailored to ineet an identifiable market

146. See, e.g., Brennan, Local Government Action and Antitrust Policy: An Economic Analysis, 12 Fordham URB. L.J. 405, 430-36 (1984); Cirace, An Economic Analysis of the "State-Municipal Action" Antitrust Cases, 61 TEX. L. REv. 481 (1982); Wiley, supra note 65, at 743-88.

147. See supra note 20; Garland, supra note 78, at 508-12; Hovenkamp \& Mackerron, supra note 16 , at $758-59$.

148. In light of Garcia, there should be no tenth amendment prohibition to such congressional action. See supra note 18 . Of course, a sensitivity to economic federalism might require that Congress exercise such power expressly and clearly. 
failure. This approach would obviously intrude directly into state affairs and require federal courts to inake difficult decisions. Alternatively, Congress inight respond on a process basis by expanding the Court's current lenient process review. For example, the state action exemption inight be available only when the state or local governmental unit proposing the regulation (1) identifies a market failure that the regulation purports to remedy, (2) holds public hearings to discuss whether competition should be supplanted with regulation, ${ }^{149}$ and (3) sets forth in writing the government's reasons for adopting regulation instead of competition. ${ }^{150}$ Or, Congress might accoinphish similar results by requiring that a state or mumicipality produce a "Conipetitive Impact Statement" before adopting and implenienting a regulatory scheme. ${ }^{151}$ This sort of process-oriented response may well be preferable to a substantive approach because it retains a significant role for states im the regulation and control of their economies, and yet also helps inform state regulators which in turn may deter blatantly mefficient regulation.

\section{Spill-Over Costs}

When state or local regulations produce inefficiencies that fall beyond the boundaries of the regulatimg governmental umit and thus are visited upon nonresidents, spill-over costs (or "externahities") result. Regardless of one's position with respect to general allocative inefficiency costs resulting from state or local regulation, spill-over costs are of special concern because they are borne by citizens who do not have the opportunity to participate in the decision to supplant competition with regulation. ${ }^{152}$

Spill-over costs are common in the area of environmental regulation; for instance, a state may reduce its air or water pollution standards to attract industrial development although soine of the harns of reduced air and water quality will fall outside the regulatimg jurisdiction. Significant spill-over costs may also result from basic economic regulation. State regulation that raises the price of goods or services produced within the state creates spill-over costs when a substantial portion of these costs affects consumers outside the state who purchase the goods and services. For example, California's restrictive regulation of raisin production, upheld in Parker, caused the price of raisins to rise; the higher prices fell

149. Congress inight also permit, indeed encourage, out-of-state parties and the Department of Justice to participate and coininent upon the anticompetitive effects of proposed state regulation.

150. Compare Federal Energy Regulatory Comm'n v. Mississippi, 456 U.S. 742 (1982) (affirming similar process-oriented requireinents for state energy regulation).

151. Compare Environineutal Inpact Stateinent Requireınents and Procedures, 40 C.F.R. $\S 6.105$ (1986).

152. See Easterbrook, Antitrust and the Economics of Federalism, 26 J. L. \& EcoN. 23, 46 (1983); Hovenkamp \& Mackerron, supra note 16, at 768-71. 
primarily upon outsiders because ninety percent of the raisin crop was shipped to purchasers outside the state of California. ${ }^{153}$ Another example is a state regulation that permits the cartehzation by horizontal competitors of research and development activities or other aspects of production and sales. ${ }^{154}$ While the regulated activity of research and development may be contained within the boundaries of the state, the results-which could be anticompetitive if measured by the federal antitrust laws-may be exported to consumers throughout the nation. ${ }^{155} \mathrm{~A}$ more extreme example would be state or regionally ${ }^{156}$ sponsored "crisis cartels" in which markets are allocated or production quotas set among competitors in "sick" or declining industries.

Spill-over costs resulting froin state or local regulation could be substantial but it is not obvious how such costs should be dealt with. The negative commerce clause doctrine is one possible approach. ${ }^{157}$ But that doctrine has proven difficult to apply and also inay be considered too weak to eliminate exported costs. Alternatively, Congress could intervene and ainend the antitrust laws, or the federal courts inight further develop the state action doctrime to prohibit substantial spill-over costs. ${ }^{158}$

The negative commerce clause doctrine prohibits states from enacting legislation that discriminates against outsiders or unduly burdens interstate commerce. ${ }^{159}$ In the recent Brown-Forman case, ${ }^{160}$ the Supreine Court articulated a two-tier test for state economic regulation: a state statute will be upheld if it is nondiscriminatory and if the state's legitimate interest in the statute is not exceeded by coinpeting national interests. ${ }^{161}$ Thus, even if a state regulation were exempt from the anti-

153. Under the facts of Parker, the regulation probably would have been upheld even if the Court had focused upon spill-over costs, because the state regulation was arguably consistent with federal legislation and congressional intent to regulate such agriculture. See Levmore, Interstate Exploitation and Judicial Intervention, 69 VA. L. REV. 563, 628 (1983).

154. Such a proposal for the State of California has been discussed with the author.

155. Shared R\&D among dominant firms in an oligopolistic market, for example, could result in shared information concerning costs, production methods, or other aspects of doing business that might carry over into pricing or production decisions.

156. For an example of states cooperating as a region and obtaining state action immunity from the antitrust laws for their joint activities, see $S M C, 471$ U.S. 48.

157. See, e.g., Page, supra note 5, at 1107.

158. See, e.g., Easterbrook, supra note 152, at 45-46. The Court's state action opinions neither discuss the problem of spill-overs nor suggest solutions. The plurality opinion in Lafayette, 435 U.S. at 403-08, is an exception, in that it discusses the problem of parochial regulation affecting outsiders.

159. The negative commerce clause doctrine grows out of the Constitution's affirmative grant of federal commerce clause power. U.S. ConST. art. I, $\$ 8 \mathrm{cl}$. 3. See generally L. TRIBE, AMERICAN CONSTITUTIONAL LAW, $\$$ 6-1 to -27 (1978).

160. Brown-Forman Distillers Corp. v. New York State Liquor Auth., 106 S. Ct. 2080 (1986).

161. The Court said:

This Court has adopted what amounts to a two-tiered approach to analyzing state economic regulation under the Commerce Clause. When a state statute directly regulates 
trust laws under the Court's new, lenient process standard for state action exemption, the commerce clause might stand as a separate obstacle that the state nuust overconie.

Considerably more work must be done to sort out fully the relationship between the state action doctrine and the negative commerce clause doctrine. As presently interpreted, the negative commerce clause doctrine may not effectively catch spill-over costs. It has been a difficult doctrine to understand and apply with confidence: what constitutes discrimination is elusive and balancing federal and state interests challenges the capacities of federal courts. ${ }^{162}$ Moreover, it is arguable that the state action doctrine and the negative commerce clause doctrine, when applied to state economic regulation, completely overlap. In other words, the implied congressional intent that informs the state action doctrine and the scope of the negative commerce clause may be essentially the same; therefore, a state statute that satisfies one doctrine should also satisfy the other. These potential difficulties with the negative commerce clause doctrine might indicate that other avenues of addressing spill-over costs should be explored.

Congress, of course, could intervene and make clear that the state action doctrine does not immunize state regulation that produces substantial harms in jurisdictions outside the regulating state. Congress would then have to define spill-overs and determine when they should be considered substantial. If the ainended statutory language were kept on a general, exhortative level, as would seen likely, the federal courts would soon be involved interpreting the amendments in subsequent cases. An alternative congressional approach might focus on process. Rather than directly prohibit spill-over costs, Congress might instead require states to hold hearings to consider the possible spill-over effects of proposed state regulation and to permit out-of-state parties to participate in such hearimgs. ${ }^{163}$

or discriminates against interstate commerce, or when its effect is to favor in-state economic interests over out-of-state interests, we have generally struck down the statute without further inquiry. . . When, however, a statute has only imdirect effects on interstate commerce and regulates evenhandedly, we have examined whether the State's interest is legitimate and whether the burden on interstate commerce clearly exceeds the local benefits.

Id. at 2084 (citations omitted).

162. See L. TR1BE, supra note 159; Dowling, Interstate Commerce and State Power, 27 VA. L. REV. 1 (1940); Eule, Laying the Dormant Commerce Clause to Rest, 91 YALE L.J. 425 (1982); Levmore, supra note 153; Maltz, How Much Regulation Is Too Much-An Examination of Commerce Clause Jurisprudence, 50 GEO. WASH. L. REv. 47 (1981); Regan, The Supreme Court and State Protectionism: Making Sense of the Dormant Commerce Clause, 84 Mich. L. REV. 1091 (1986); Smith, State Discriminations Against Interstate Commerce, 74 CAL1F. L. REv. 1203 (1986).

163. Congress might also require that states permit the Department of Justice to participate and articulate its views concerning the anticompetitive and spill-over effects of proposed state regulation. See also the process-oriented suggestions noted at text accompanying notes 149-51 supra. 
Finally, the federal courts might address the problem of state action spill-overs without waiting for congressional action. The state action doctrine was judicially created and thus might be refined by the courts to make clear that state regulation producing substantial spill-over costs is not exempt from the antitrust laws. Parker's solicitude for the regulatory activities of states need not be read to extend to the extrajurisdictional exportation of substantial costs. The legislative history of the Sherman Act, it might be argued, does not demonstrate that Congress intended to immunize from the antitrust laws state regulation producing such spillover costs. Moreover, from the perspective of economic federalism values, spill-over costs are contrary to the values of citizen participation and governmental efficiency. State regulations producing such costs, therefore, do not deserve deference. Such state regulatory activities would remain subject to the force of the antitrust laws. ${ }^{164}$

\section{CONCLUSION}

The Court's decisions in Hoover, Hallie, SMC, and 324 Liquor greatly clarify the state action doctrine and return it to its federalism roots. The Court's lenient process-oriented test for identifying exempt state action defers to state economic decisions and advances the federalism values of citizen participation in government, efficiency in government, creative experimentation, and diffusion of power. Indeed, the importance of citizen participation may help explain the Court's continued insistence on active supervision of delegations of regulatory authority to private parties.

Deferential economic federalism, however, may lead to allocative inefficiencies and spill-over costs. The former may be expected in a federalist system of government that gives states room to determine their own mix of competition and regulation, but spill-over costs are not justified by federalism values. Further research efforts in the state action area should attempt to identify and quantify these costs, with a view toward developing legal doctrine in a manner that is sensitive to the values of federalism, yet capable of filtering out state activities that produce substantial costs.

164. One of the difficulties of applying the antitrust laws to such state activities, instead of simply preempting the offending statute (as would happen under negative commerce clause analysis) is that the Court must then conduct further antitrust analysis. This would require a court to resolve what legal standard must be applied to a state or municipality-rule of reason or per se analysis. Further, a court would have to resolve whether a state might be held liable for treble, rather than single, damages. See supra note 71 . Justice Rehnquist pointed out these difficulties in his dissent in Boulder, 455 U.S. at 60,65 , and they have not yet been resolved. 